simultaneous transformation. Such a view is not opposed by the palæontological evidence.

In the ensuing general discussion Prof. Westoll noted that the Theriodonts show several features indicating the piecemeal acquisition of mammalian characters. If one bases classification solely on the presence or absence of the mammalian temporomandibular joint, then pouch-young of some marsupials and even an occasional lamb at birth are reptiles.

Lieut.-Colonel L. M. Davies spoke as one to whom evolution is a fact yet to be proved, and pointed out the enormous differences between a bird's feather and any reptilian dermal structures. He asked how such things could happen as a result of explosive evolution. It was pointed out that 'explosive' is a word implying comparative rather than absolute speed of evolution, and that in any case the history of the birds is very badly known. Other speakers discussed giantism in various aspects, and a case of genetically controlled hyperpituitarism was mentioned.

T.S.W.

\section{SURVEYS OF UNDER-DEVELOPED AREAS}

T

HE Duke of Edinburgh referred in his presidential address at the British Association to the various shortages which the world is now facing and which are "partly due to the huge inevitable waste of war and its consequences, and partly to the lack of any comprehensive survey of the world's resources and requirements". "It is only," the Duke continued, "by an accurate knowledge of the world's resources that we can foresee the scope and magnitude of the future problems which science and technology have to meet and which only they can solve." For a whole day, on August 14, an inter-section discussion was concerned with the need for the assessment of the resources of those areas that seem to the rest of the world to be undeveloped or under-developed and about which extravagant claims are often made. At the end of the day one of the speakers commented that, from the dozen or so papers read, one thing stood out most clearly-namely, that as scientific men, all recognized the need for more facts. Especially was there a need for the establishment of the facts by preliminary surveys. To make haste slowly was the speediest, as well as the surest, way of developing areas for the benefit both of their inhabitants and of mankind generally.

The importance accorded by scientific workers to the problems of the economic development of the under-developed parts of the world was shown by the number of Sections collaborating-E (Geography), C (Geology), D (Zoology), K (Botany), M (Agriculture) and $F$ (Economics)-and by the size of the audience throughout the morning session. The problem of these areas has been posed by the politicians, notably by President Truman in Point Four of his address to Congress in 1949 : "We must embark on a bold new program for making the benefits of our scientific advances and industrial progress avail able for the improvement and growth of underdeveloped areas". But it falls to scientific workers to show just how these benefits are to be brought to such regions, and the discussion made it clear that there are no short cuts and no easy solutions, and that a tremendous diversity of conditions must be encountered. Prof. L. Dudley Stamp, who opened the discussion, claimed that the huge losses incurred in the Tanganyikan groundnut and the Gambian poultry schemes showed convincingly that, apart from any possible political or financial mismanagement, there is at present inadequate knowledge on which to base development schemes in underdeveloped lands, especially in the tropics.

Prof. Stamp explained the purpose and organization of the World Land. Use Survey, of which he is director of the Old World Division. He elaborated the aims of this fact-finding survey-to record the existing use of the land and to attempt to ascertain the reasons why the land is used as it is-along lines similar to those of his article in Nature of June 23, p. 1010. The need for objectivity, he said, is paramount : if subjective judgments are introduced, the value of such a Survey will be greatly reduced. For these and other reasons, the Survey recommends that. any map prepared should be, like the one-inch map, 'survey accurate', even though the final product. covering the whole world will be only on the scale of one to one million. The land-use classification drawn up by a Commission of the International Geographical Union is designed to cover as many different categories of land use as possible in regions as diverse and as distant from one another as Thailand, northern Canada and tropical Africa. An essential prerequisite of development anywhere in the world, whether well known and intensively used or unknown and undeveloped, must be a record of the present position and the causes that lie behind it: in Prof. Stamp's phrase, there must first of all be a "synoptic, objective view".

Fifteen years ago the prospects of such a world survey would have seemed meagre indeed, and even to-day the financial problems are large and as yet unsolved. But, as several speakers pointed out, the use of air photographs in mapping now makes possible the covering of much of the world, including many of the under-developed areas. In the absence of Brigadier M. Hotine, the director of Colonial Surveys, Lieut.-Colonel G. J. Humphries described the comprehensive and ever-increasing range of the activities of that Directorate since its establishment in 1946, and discussed some of the difficulties encountered both at headquarters and in the Colonial territories. $\mathrm{He}$ explained the adoption of the scale of $1 / 50,000$ as being the one that most nearly meets the requirements of most users of the maps. Contouring remains the chief bottle-neck; hence the issue of 'preliminary plots' in black-and-white only, and with hachuring to indicate certain relief features; but fully coloured, contoured maps will be available later once the immediate and pressing demands of the development plans of all British Colonies have been met. Later in the discussion, Mr. T. D. Weatherhead, director and general manager of Hunting Aerosurveys, Ltd., gave illustrations of how his company's photographs have helped agricultural and planning authorities and guided geologists in undertaking their field-work. He believed that the problem of speedy contouring can be overcome by the wider use of aids such as the airborne profile-recorder.

Two geographers spoke of land-use surveys with which they had been associated and thus illustrated both the potentialities and the problems of so vast a project as a world survey of land use. Dr. J. Wreford Watson, head of the Geographical Branch, Department of Mines and Technical Surveys, Canada, showed how geographers are employed by the 
Canadian Government "to survey conditions as they are, ... geography being regarded as a factual not a remedial aid to government", and described the regional surveys made in different parts of Canada. $\mathrm{He}$ pointed out that the size of Canada makes a ficld-by-field survey impossible and compols the use of the sampling method, larger areas being interpreted by detailed studies of typical samples. In his view the success of the World Land Use Survey will depend on its inclusive categories and its generalized scale. Mr. R. M. Prothero, of University College, Ibadan, described some of the problems of land-use mapping in the forest areas of southerm Nigeria, stressing the lack of map-cover in many tropical regions and the difficulties in interpreting air photographs-such as the problem of the identification of cacao, especially in a country with thousands of very small farms. Nevertheless, his preliminary investigations in an area north of Ibadan gave some interesting information that is so often impossible to come by in the tropics, namely, data concerning, for example, bush fallows and the amount of land available for cultivation.

Most of the fields of science concerned in the carrying out of surveys were represented in the discussion, though there was no forestry contribution - an unfortunate omission in view of the breadth of view so characteristic of forestry departments and of individual foresters in many under-developed areas. Prof. T. N. George, of Glasgow, spoke of the geologist's interest in the problems of development. $\mathrm{He}$ described how in the past a high proportion of the time of geological surveys was taken up by the investigation of mineral deposits of possible commercial significance, and showed how the question of development still turns largely upon the nature of the economic conditions prevalent at any particular time. The contribution of the soil scientist was emphasized by several speakers, and especially by Dr. Herbert Greene, adviser on tropical soils at Rothamsted Experimental Station. He recognized four factors that have made soil survey easier and more significant during the past twenty-five years : the use of air photography; the concept of soil associations fashioned in East Africa by the late Geoffrey Milne and his colleagues; the discovery of insecticides and drugs that make possible the occupation of vast areas, especially in tropical lowlands, that were not previously available; and the principle of what he termed 'beneficial use', whereby the communal interest and the sense of partnership were seen to matter more than any individual claims to rights in land or water. At the same time, he directed attention to the problems in certain under-developed areas where nationalism seeks the fruits of technology but rejects the foreign technician. He was convinced that the British are right in their policy of encouraging the nationals of such areas to take an active and responsible share in the work of development : thus, and only thus, will they appreciate that the limitations on development are imposed not by the whim of an alien power but by the natural conditions.

"A Zoological Contribution" was the title of Dr. E. B. Worthington's paper, read for him in his absence ; but Dr. Worthington speaks as much more than a zoologist, because of his outstanding work for all the sciences in Africa and in virtue of his position as secretary-general of the Scientific Council for Africa South of the Sahara established last year. This Council, an international body, is, he suggested, rightly conceived, since science can know no frontiers, and it would take great notice of this discussion by British scientific men of the problems of under-developed areas. $\mathrm{He}$ pointed out how considerable is the scientific potential of Africa to-day, especially on the biological side, largely as a result of wise spending by the metropolitan and Colonial governments and through the establishment of the Colonial university colleges and research institutions in British and non-British territories. The tsetse fly has so far saved much of Africa from disorderly developmentin contrast to parts of the Far East and south-east Asia-and in his view there is still time to bring science to bear upon African problems, though he foresaw serious difficulties arising from the rapid growth of population in certain areas.

Most time was not unnaturally devoted to the huge under-developed parts of Africa, but several speakers besides Dr. Watson directed attention to other areas. Miss A. G. Donnithorne spoke of a rather different type of survey, that of the economist. She dealt with the Far East, citing in particular the work done in China by the selection of samples by Prof. Buck and his associates. Dr. C. F. Hickling, fisheries adviser to the Secretary of State for the Colonies, discussed fisheries in all parts of the world and showed that fisheries often represent undeveloped food supplies even in countries that are otherwise well developed : many tropical waters are not merely undeveloped but quite unexplored. The Colonial Office is establishing fisheries research stations and fisheries departments which will concentrate on the development of existing fisheries and the improvement of methods of catching and preserving. Care is being taken to avoid the heavily capitalized unit and to enlist, wherever possible, the co-operation of the local fisher-folk. Sir Geoffrey Evans, of the Royal Botanic Gardens, Kew, focused attention on the land settlement problems of those areas round the Caribbean that he knows so well, and where it is hoped that homes may be created in British Guiana and British Honduras for some of the growing populations of the West Indian islands. He stressed the need for preliminary surveys, especially of soils, before the possibility of rail or road construction (essential for any real development) can be entertained. One of the world's basic problems to-day is, in his opinion, that of food supplies in relation to a rapidly increasing population. Contrary to a commonly held view, there are not large areas of first-class land in the virgin tropics capable of producing food : there is, he claimed, far more second-class and marginal land.

It must be recognized, moreover, that not all the under-developed lands are uninhabited, and this in itself gives rise to a whole series of problems. Dr. Greene doalt with the difficulties of partnership, and the several references made by different speakers to human values and relationships made it clear that scientific workers fully recognize their great significance. No speaker put this better than Dr. A. S. Thomas, principal scientific officer of the Nature Conservancy, with a wide experience of tropical Africa. "Development," he said, "is not merely a matter of production and exports, or even of hospitals and schools, but of human development and human happiness. We must preserve this happiness of the people until we know more, not only about their crops, but about them also." Here Dr. Thomas was bringing together the concern of all the sciences. He showed, too, how false are many of the common generalizations about the tropics, and how misleading can be the experience of temperate lands when 
applied to tropical conditions. We are still grossly ignorant of the interaction of all the factors that control plant growth near the equator, and this information can, he claimed, be gathered in only one way-by the slow, careful, even laborious method of the preliminary, detailed survey. "The more revolutionary the cultural methods to be used," he warned, "the greater the need for pilot schemes and for working in small units."

Statements like these do not appeal to the politician or to the official who wants quick returns and speedy and convincing results. But they are typical of the caution and realism of the scientific worker and, significantly, were endorsed by all those taking part in the discussion. They are clearly the convictions of the organizers of the World Land Use Survey, which will provide an objective record of the existing facts of land use and which is intended as a foundation for schemes of improvement and development in all parts of the world. It is to be hoped that a small part at least of the many millions at present available for development and welfare schemes will be directed towards this Survey in different countries, so that it may speedily be established on a permanent basis. Here is a project in which all the sciences are interested and all men of science can, and should, co-operate : and it cannot fail to make a real and substantial contribution to the scientific study of under-developed, as well as other, areas and also to the progress and happiness of those who are sometimes termed the world's under-privileged peoples.

ROBERT W. STEEI

\section{NEWS and VIEWS}

\section{Sir Arthur Fleming, C.B.E.}

AFrer fifty years of distinguished service to the causes of industrial research and the education and training of industrial personnel, Sir Arthur Fleming has resigned his post as director of research and education to the Metropolitan-Vickers Electrical Co., Ltd., although he will remain $a_{0}$ director of the firm; he has also agreed to assume general direction of research and education for the group of electrical firms known as A.E.I., Ltd. The Research Laboratories at Trafford Park, Manchester, which Sir Arthur was responsible for creating and developing, have produced outstanding contributions to scientific and technical knowledge and achievement over a very wide field, and have afforded unique opportunities to a long succession of investigators many of whom have attained eminence in their respective subjects. $\mathrm{He}_{\Theta}$ will be most remembered, however, for the influence he has exerted on technical education in Great Britain. The number of apprentices and trainees of all grades for whom systematic training has been provided in the Metropolitan-Vickers works now totals more than ten thousand, and a glance through the register of them, published a short time ago, reveals the amazing extent to which these facilities have benefited the electrical industry as a whole, the government services and the educational institutions of the country ; and have also provided trained personnel for almost every other country. The Metropolitan-Vickers training scheme acquired a world-wide reputation many years ago, and established a pattern which has been widely adopted.

Sir Arthur's activities have not been confined to Metropolitan-Vickers. His knowledge and experience have been placed unsparingly at the disposal of numerous societies, the universities and government establishments, and, in particular, he has held the positions of president of the Institution of Electrical Engineers and of both the Engineering and Education Sections of the British Association. He has been the recipient of many honours, including the Faraday Medal of the Institution of Electrical Engineers and the Hawksley Medal of the Institution of Mechanical Engineers; he was granted the degree of D.Eng. honoris causa by the University of Liverpool; was appointed O.B.E. in 1918 and C.B.E. in 1920 for his work on submarine detection, and in 1945 was knighted for his outstanding services to education. Sir Arthur retains remarkable physical and mental vitality, and it is to be hoped that he will long continue to give industry and education the benefit of his far-sightedness and intense enthusiasm.

\section{Dr. C. Dannatt, O.B.E.}

Dr. C. Dannatr, who succeeds Sir Arthur Fleming at Manchester, has had some thirty years service with the Metropolitan-Vickers Electrical Co. After military service in the First World War, he graduated in electrical engineering from the University of Durham and went to Metropolitan-Vickers in 1921 as a college apprentice. He joined the Research Department in 1922 and over many years has built up a very close association between the Research and Engineering Departments of the Company on design and related matters. $\mathrm{He}$ is the author of many papers and articles on electrical engineering subjects, and in 1936 was awarded the D.Sc. degree of Durham. In 1940 Dr. Dannatt was appointed to the chair of electrical engineering in the University of Birmingham; but due to war-time commitments he filled it only on a part-time basis. Before and during the Second World War he was actively associated with the Admiralty in the application of remote control to gunnery, being one of the original members of the Admiralty Remote Power Control Committee, and for this work he received the O.B.E. in 1943. In 1944 he vacated his university chair and rejoined Metropolitan-Vickers, this time on the electrical engineering side, and became in 1947 chief electrical engineer of the Company with a seat on the Board. Dr. Dannatt therefore brings to his new post a very broad understanding of the requirements of a large manufacturing organization in industrial research and also in the recruitment and training of technical staff. Coupled with his additional appointment as assistant managing director of the Company, there is every reason to believe that under his guidance the forward-looking policy of the Metropolitan-Vickers Co. in these vital activities will be fully maintained.

\section{Institute of Biology: Mr. D. J. B. Copp}

Mr. D. J. B. CopP has been appointed secretary of the Institute of Biology as from October 1. Mr. Copp is a graduate of University College, Southampton, where his studies were interrupted by the War, when he was engaged on radar research at the Admiralty Signals Establishment (Extension), Witley. In 1947 he was appointed assistant secretary of the 